\title{
DAYA TERIMA DAN KARAKTERISTIK MINUMAN SERBUK \\ 'TERAI' BERBAHAN DASAR TEMULAWAK (Curcuma xanthorriza Roxb) DAN SERAI (Cymbopogon Citratus)
}

\author{
Yola Mastika Sari ${ }^{1}$, Ayu Pravita Sari ${ }^{2}$, Miratul Haya ${ }^{3}$ \\ ${ }^{1}$ Poltekkes Kemenkes Bengkulu, ${ }^{2}$ Poltekkes Kemenkes Bengkulu, ${ }^{3}$ Poltekkes Kemenkes \\ Bengkulu \\ Email : yolamastikasari17@gmail.com
}

\begin{abstract}
Background : Powder drink is a powder or granule product that made from a mixture of sugar and spices with or without the addition of other ingredients. Raw ingredients of powder drink can make from various kinds of plants, such as turmeric and lemongrass, that are both of ingredients contain active compounds that can function to maintain body immunity, especially during a pandemic like now. The criterias of a good powder drink are taste, smell, color and appearance that are comparable to fresh products, have nutritional characteristics and have a good storage stability. Purpose : This study aims to determine the organoleptic acceptability of the "Terai" powder drink with three treatments and characteristics with the parameters of the water content and ash content of the most liked product.

Methods : This research is an experimental research or experiment (experiment research). The design used is a completely randomized design which aims to assess a treatment or action. In this study, the treatment is carried out to determine the acceptability of "Terai" powder drink based on organoleptic colour, texture, aroma, and taste carried out on 30 trained panelists as well as characteristic tests with parameters of water content and ash content of the most liked product. The tests used are KruskallWallis and Mann-Whiteney.

Results : The result test of three product (F1, F2, F3) showed there was a difference of color receivability organoleptic $(p=0,000)$ and taste $(p=0,004)$, and smell receivability organoleptic $(p=0,273)$ and texture $(p=0,288)$ shwed there was no difference. So for receivability orgaanoleptic of colour and taste to be continued with Mann-Whitney test. . The result of the characteristic test with the water content parameter was $7.22 \%$ and the characteristic test result with the ash content parameter was $2.11 \%$ for the most preferred product.

Conclusion : From three of 'Terai' powder drink's formulation showed that the most liked product is F2 with the water content 7,22\% and the ash contenct $2,11 \%$.
\end{abstract}

keywords : characteristics, lemongrass, powder drink, receivability, turmeric 


\section{PENDAHULUAN}

Produk minuman merupakan salah satu produk yang banyak digemari oleh masyarakat. Berbagai macam minuman kini telah banyak dikembangkan, salah satu yang marak tersebar di pasaran adalah minuman serbuk. Minuman serbuk merupakan produk bahan minuman berbentuk serbuk atau granula yang dibuat dari campuran gula dan rempahrempah dengan atau tanpa penambahan bahan makanan lain. Kriteria minuman serbuk yang baik antara lain mempunyai rasa, bau, warna, dan kenampakan yang sebanding dengan produk segar, memiliki karakteristik nutrisi serta mempunyai stabilitas penyimpanan yang baik. Bahan baku minuman serbuk dapat berasal dari berbagai macam tanaman, termasuk juga rempah temulawak dan serai (SNI, 1996).

Temulawak (Curcuma Xanthoriza Roxb) merupakan bahan yang sangat strategis untuk dikembangkan mengingat banyaknya manfaat yang ditunjukkan oleh bahan aktif kurkuminoid. Temulawak mengandung air sekitar 75\%, selain itu mengandung minyak atsiri, lemak, zat warna, protein, pati, mineral, dan zat-zat aktif lainnya (Cahyono et al., 2011).

Temulawak telah digunakan secara luas dalam berbagai industri, diantaranya dalam bidang industri makanan, minuman, obat-obatan, tekstil dan kosmetik. Dalam industri minuman, temulawak dapat dimanfaatkan sebagai pangan fungsional yang diolah dalam bentuk minuman serbuk yang kaya akan manfaat (Br. Sembiring et al., 2015).

Serai atau Lemongrass (Cymbopogon Citratus) merupakan tanaman yang dibudidayakan di pekarangan dan sela-sela tumbuhan lain. Tanaman ini diyakini sebagai tanaman obat yang mengandung berbagai senyawa bioaktif yang bermanfaat sebagai antioksidan, anti-diabetes, anti-malaria, anti-hepatotoxic, anti-obesitas, antihipertensi, dan aromanya mampu mengatasi kecemasan (Widiastuti et al., 2018).

Serai biasanya digunakan untuk kebutuhan memasak dan obat-obatan. Namun karena senyawa bioaktif yang terkandung didalamnya, tanaman ini juga dapat mengobati infeksi kulit, tipus, keracunan makanan, serta dapat juga meredakan bau badan (Arisanti \& Mutsyahidan, 2017).

Senyawa bioaktif dapat bermanfaat sebagai antioksidan yang dapat meningkatkan imunitas tubuh. Untuk menjaga imunitas tubuh agar tetap baik salah satunya dapat melalui makanan dan minuman yang dikonsumsi, terutama pada bahan makanan yang 
mengandung antioksidan tinggi yang sangat diperlukan tubuh saat pandemi Covid-19 seperti saat ini (Cahyani \& Rustanti, 2015).

Sebagai pangan fungsional yang diolah dalam bentuk minuman serbuk, tentunya terdapat beberapa karakteristik atau syarat mutu yang harus dipenuhi agar sesuai dengan standar SNI minuman serbuk yang layak untuk dikonsumsi. Syarat mutu minuman serbuk menurut SNI terdiri dari beberapa parameter, yaitu warna, bau, rasa, kadar air, kadar abu, jumlah gula, kadar pemanis buatan, kadar pewarna tambahan, kadar cemaran logam, kadar cemaran arsen, dan kadar cemaran mikroba (SNI, 1996).

Hasil penelitian (Moehady, 2015) menunjukkan bahwa dari uji organoleptik yang dilakukan pada produk minuman temulawak yang paling disukai dari rasa dan baunya yaitu dengan komposisi 3 g serbuk temulawak dalam sirup $150 \mathrm{ml}$ larutan gula, dan warna sirup secara visual yang paling pekat dan nilai indeks biasnya paling besar yaitu dengan komposisi serbuk temulawak $6 \mathrm{~g}$ dalam sirup $150 \mathrm{ml}$ minuman serbuk temulawak.

Penelitian (Rakhmad, 2017) mengatakan perlakuan terbaik dari produk minuman serbuk temulawak yang diolah memiliki karakteristik kadar air 7,48\%, sedangkan menurut (Cahyono et al., 2011) hasil penelitian menunjukkan bahwa kandungan air pada semua sampel penelitian yang dilakukan sekitar 4,06\%-7,76\%.

Hasil daya terima minuman serbuk serai yang dikombinasi dengan kayu manis menurut (Arisanti \& Mutsyahidan, 2017), tingkat kesukaan panelis terbaik yang dihasilkan dari 3 atribut (warna, aroma, dan rasa) adalah perlakuan penggunaan daun serai 1,5 g dengan kombinasi kayu manis 0,2 g. Sedangkan berdasarkan penelitian (Widiastuti et al., 2018) minuman serbuk temulawak yang paling disukai adalah dengan formulasi $100 \mathrm{ml}$ ekstrak stevia dan $125 \mathrm{ml}$ ekstrak serai, dengan warna kecoklatan, rasa sedikit manis dan beraroma serai.

Hasil analisa karakteristik minuman dilihat dari rata-rata kadar air pada teh serai kayu manis menurut (Arisanti \& Mutsyahidan, 2017) berkisar antara 6,08-7,57\%. Dan untuk kadar abu berkisar antara 5,00-6,42\%.

Menurut (Kristiani, 2013) peminat minuman serbuk yang semakin meningkat menyebabkan banyak produsen pangan membuat minuman serbuk tanpa memerhatikan manfaat untuk kesehatan. Karena adanya pemanis, pewarna, perasa buah-buahan, 
seringkali mendominasi dalam pembuatan suatu produk pangan, kondisi ini memberikan peluang untuk membuat minuman serbuk yang bisa memberikan khasiat untuk kesehatan.

Produk minuman serbuk berbahan dasar rempah tersebar luas di pasaran dengan berbagai macam harga, mulai dari serbuk temulawak dengan kisaran harga Rp30.000Rp50.000 per kilo, serbuk serai dengan kisaran harga Rp30.000-Rp40.000 per kilo, hingga serbuk serai jahe dengan kisaran harga hingga Rp100.000 per kilo. Melihat dari manfaat kesehatan yang ada pada tanaman temulawak dan serai, maka dilakukanlah inovasi pembuatan minuman serbuk berbahan dasar temulawak dan serai yang dinamakan Minuman Serbuk 'Terai' yang kemudian akan dilakukan uji karakteristik dengan parameter kadar air dan kadar abu, lalu dibandingkan dengan standar syarat mutu minuman serbuk menurut SNI.

\section{METODE}

Penelitian ini adalah penelitian yang bersifat eksperimen atau percobaan (experiment research). Rancangan yang digunakan adalah Rancangan Acak Lengkap (RAL) yang bertujuan untuk menilai suatu perlakuan atau tindakan. Dalam penelitian ini perlakuan dilakukan untuk mengetahui daya terima minuman serbuk 'Terai' berdasarkan organoleptik warna, tekstur, aroma, dan rasa yang dilakukan terhadap 30 orang panelis terlatih serta uji karakteristik dengan parameter kadar air dan kadar abu pada produk yang paling disukai.

Penelitian ini menggunakan rancangan eksperimen dengan menggunakan dua faktorial yaitu perbandingan serbuk temulawak dan serbuk serai, F1 dengan perbandingan $1: 4$, F2 dengan perbandingan $4: 1$, dan F3 dengan perbandingan $1: 1$.

Data yang diperoleh dari uji organoleptik dianalisa secara statistik menggunakan Uji Kruskall-Wallis dan jika hasilnya ada perbedaan maka digunakan uji lanjut MannWhitney. 


\section{HASIL}

a. Daya Terima Organoleptik Mutu Warna Minuman Serbuk 'Terai'

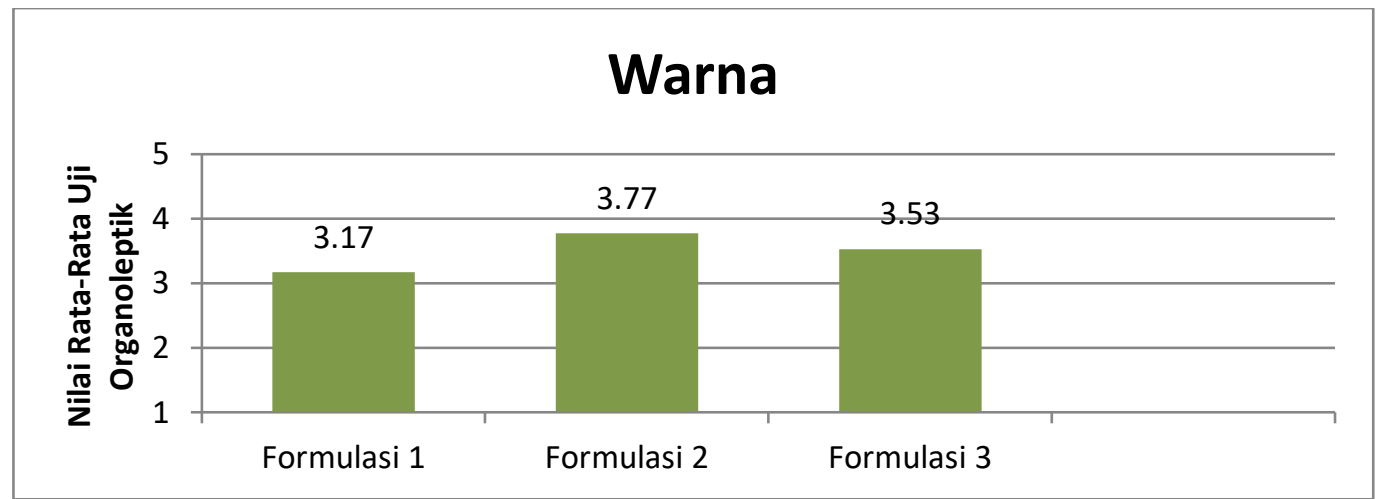

Gambar 1. Nilai Rata-Rata Uji Organoleptik Mutu Warna

Gambar 1 menunjukkan bahwa formula yang paling disukai dari mutu warna adalah F2 dengan nilai rata-rata 3,77 dan formula yang paling itdak disukai adalah $\mathrm{F} 1$ dengan nilai rata-rata 3,17.

b. Daya Terima Organoleptik Mutu Tekstur Minuman Serbuk 'Terai'

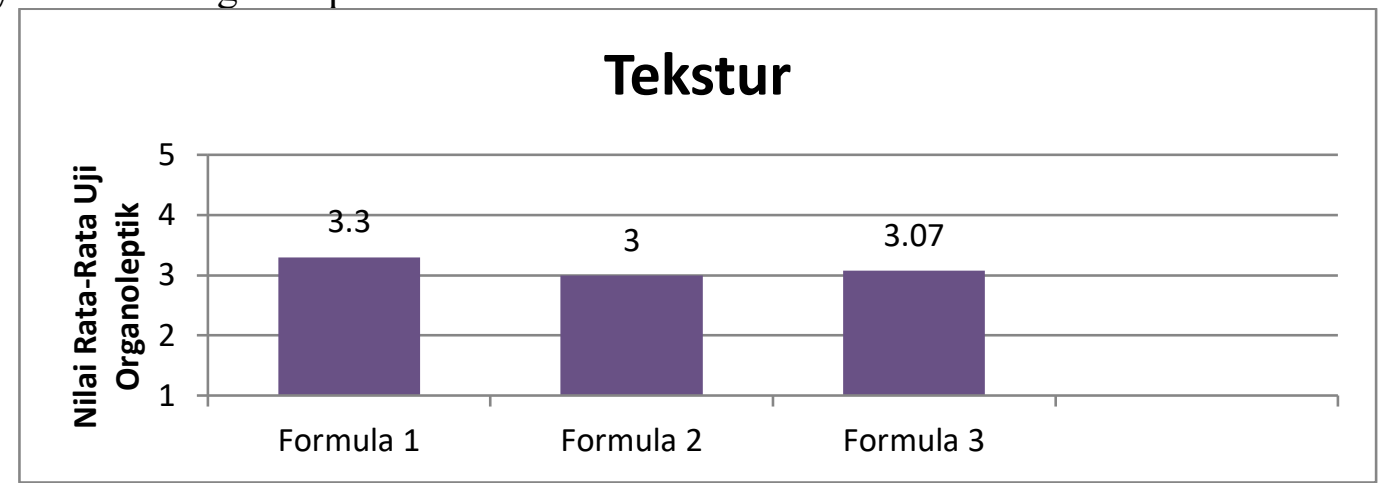

Gambar 2. Nilai Rata-Rata Uji Organoleptik Mutu Tekstur

Gambar 4.2 menunjukkan bahwa formula yang paling disukai dari mutu tekstur adalah F1 dengan nilai rata-rata 3,3 dan formula yang paling tidak disukai adalah F2 dengan nilai rata-rata 3.

c. Daya Terima Organoleptik Mutu Aroma Minuman Serbuk 'Terai'

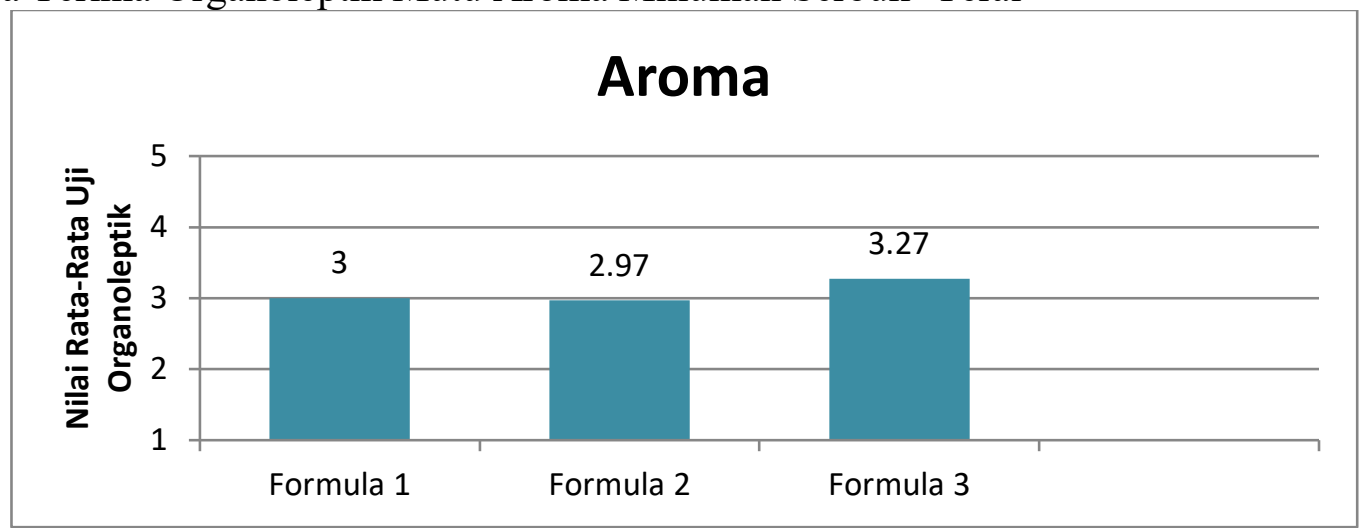

Gambar 3 Nilai Rata-Rata Uji Organoleptik Terhadap Mutu Aroma

Jurnal Vokasi Keperawatan (JVK) Volume 4 No 2 Desember 2021

Program Study of Nursing Universitas Bengkulu

http ://ejournal.unib.ac.id/index.php/JurnalVokasiKeperawatan 
Gambar 3 menunjukkan bahwa formula yang paling disukai dari mutu aroma adalah F3 dengan nilai rata-rata 3,27 dan formula yang paling tidak disukai adalah F2 dengan nilai rata-rata 2,97.

d. Daya Terima Organoleptik Mutu Rasa Minuman Serbuk 'Terai'

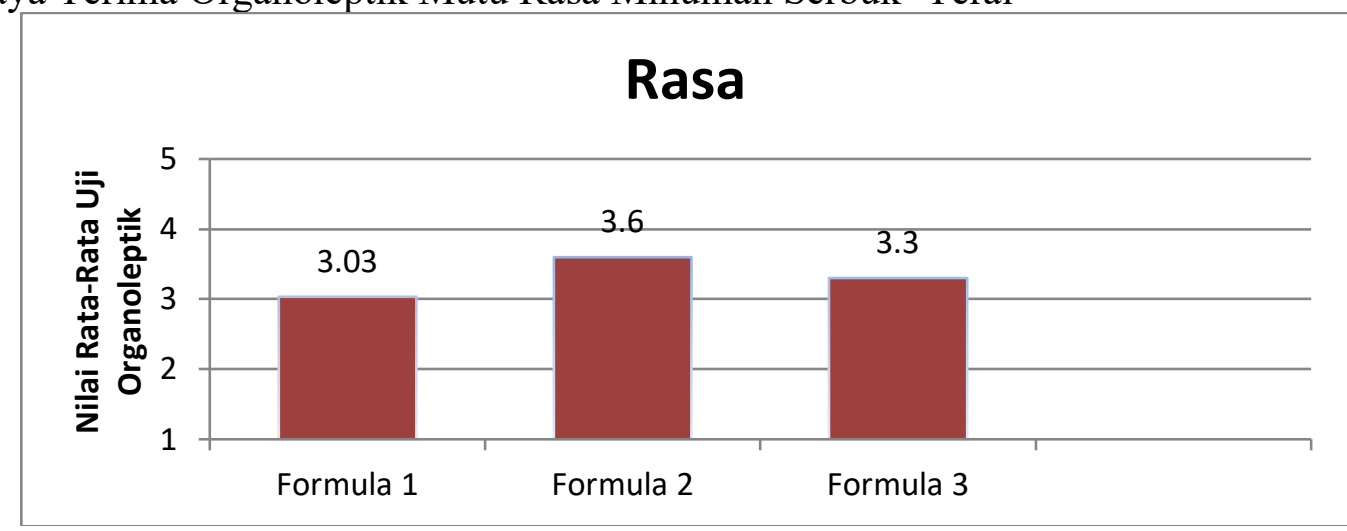

Gambar 4. Nilai Rata-Rata Uji Organoleptik Terhadap Mutu Rasa

Gambar 4 menunjukkan bahwa formula yang paling disukai dari mutu rasa adalah F2 dengan nilai rata-rata 3,6 dan formula yang paling tidak disukai adalah F1 dengan nilai rata-rata 3,03.

e. Hasil Uji Kruskall-Wallis Minuman Serbuk 'Terai'

Tabel 1. Hasil Uji Kruskall-Wallis Minuman Serbuk 'Terai'

\begin{tabular}{ccc}
\hline Mutu Organoleptik & Nilai $\mathrm{p}$ & Keterangan \\
\hline Warna & 0,000 & Ada perbedaan \\
Tekstur & 0,288 & Tidak ada perbedaan \\
Aroma & 0,273 & Tidak ada perbedaan \\
Rasa & 0,004 & Ada perbedaan \\
\hline
\end{tabular}

Keterangan :

$p>0,05$ (Tidak ada perbedaan terhadap tiga formulasi F1, F2 dan F3)

$p<0,05$ (Ada perbedaan terhadap tiga formulasi F1, F2 dan F3)

f. Hasil Uji Mann-Whitney Minuman Serbuk 'Terai'

1) Hasil Uji Mann-Whitney Mutu Warna Minuman Serbuk 'Terai

Tabel 2. Hasil Uji Mann-Whitney Mutu Warna Minuman Serbuk 'Terai'

\begin{tabular}{ccc}
\hline Perbandingan Formula & Nilai $\mathrm{p}$ & Keterangan \\
\hline F1 : F2 & 0,000 & Ada perbedaan \\
F1 : F3 & 0,006 & Ada perbedaan \\
F2 : F3 & 0,091 & Tidak ada perbedaan \\
\hline
\end{tabular}

2) Hasil Uji Mann-Whitney Mutu Rasa Minuman Serbuk 'Terai

Tabel 3. Hasil Uji Mann-Whitney Mutu Rasa Minuman Serbuk 'Terai'

\begin{tabular}{ccc}
\hline Perbandingan Formula & Nilai $p$ & Keterangan \\
\hline F1 : F2 & 0,002 & Ada perbedaan \\
F1 $:$ F3 & 0,113 & Tidak ada perbedaan \\
F2 $:$ F3 & 0,043 & Ada perbedaan \\
\hline
\end{tabular}


g. Produk Hasil Penelitian

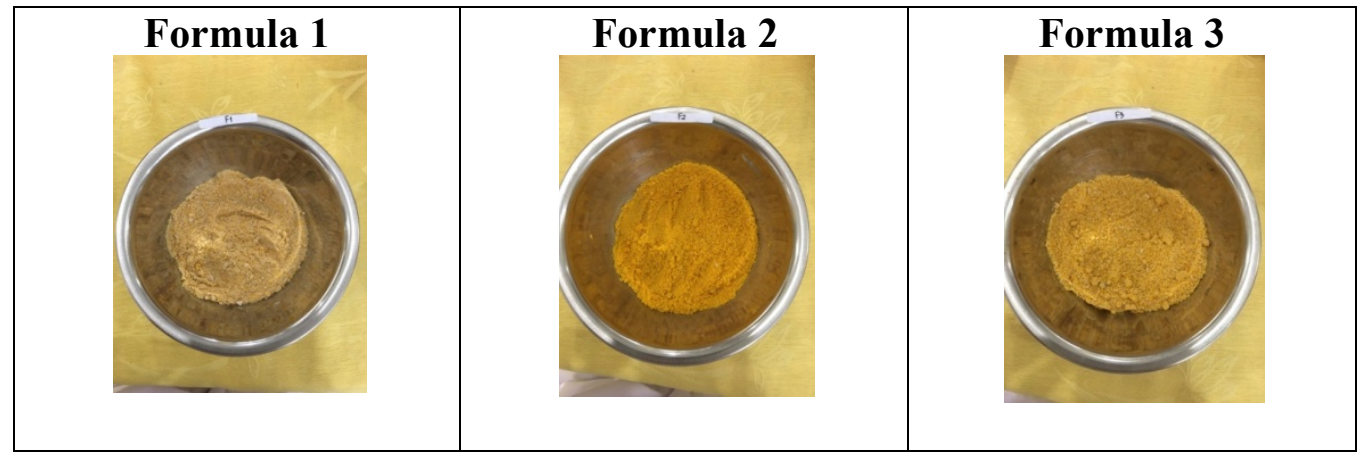

Gambar 5. Hasil Serbuk 'Terai'

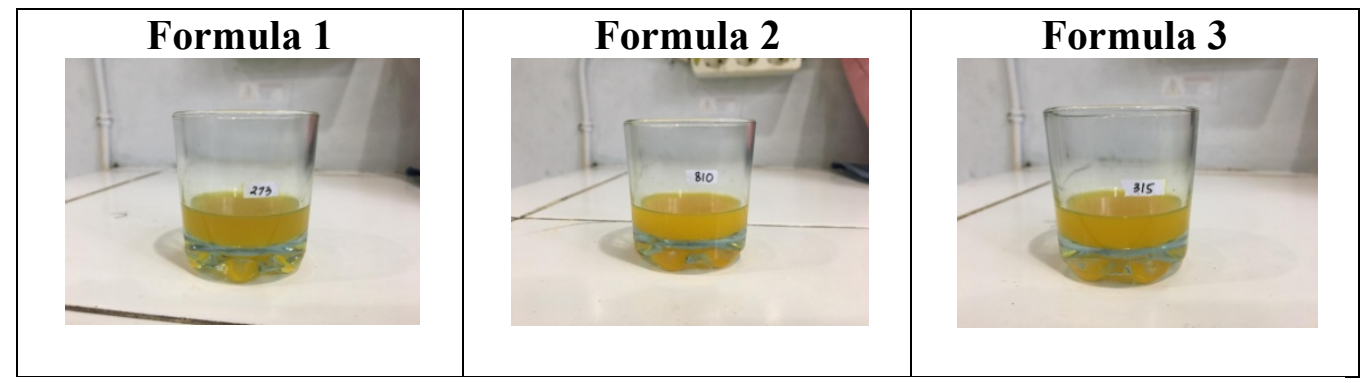

Gambar 6. Hasil Minuman Serbuk 'Terai'

h. Hasil Uji Karakteristik Minuman Serbuk 'Terai'

Dari hasil uji karakteristik dengan parameter kadar air dan kadar abu yang dilakukan pada produk yang paling disukai (F2) didapatkan hasil :

Tabel 4. Hasil Uji Karakteristik Minuman Serbuk 'Terai'

\begin{tabular}{cccc}
\hline No. & Karakteristik & Hasil & Metode \\
\hline 1. & Kadar Air & $7,22 \%$ & Thermogravimetri \\
2. & Kadar Abu & $2,11 \%$ & Pengabuan Langsung $/$ Kering \\
\hline
\end{tabular}

\section{PEMBAHASAN}

a. Daya Terima Organoleptik Mutu Warna Minuman Serbuk 'Terai'

Hasil penelitian minuman serbuk 'Terai' menunjukkan bahwa nilai rata-rata responden tertinggi atau yang paling disukai pada mutu warna adalah F2 dengan nilai 3,77. Analisis statistik pengaruh F1, F2 dan F3 menunjukkan bahwa ada pengaruh antara daya terima minuman serbuk 'Terai' mutu organoleptik tekstur $(p=0,00)$. Hasil penelitian ini menjelaskan bahwa ada perbedaan yang signifikan antara warna F1, F2, dan F3. Hal ini dikarenakan pada penelitian minuman serbuk 'Terai' dilakukan perbandingan yang berbeda antara serbuk temulawak dan serbuk serai pada F1, F2, dan F3. Pada penelitian ini kandungan curcumin pada temulawak selain berfungsi sebagai antioksidan juga berfungsi sebagai pewarna kuning alami, jadi 
semakin banyak penggunaan serbuk temulawak pada minuman serbuk 'Terai' maka warnanya akan semakin pekat (kuning).

Menurut penelitian (Moehady, 2015) bahwa dari uji organoleptik yang dilakukan pada produk minuman dengan bahan dasar temulawak yang paling disukai dari warna secara visual adalah yang paling pekat dan nilai indeks biasnya paling besar yaitu dengan komposisi serbuk temulawak 6 g. Pada penelitian ini minuman serbuk 'Terai' dinilai dari mutu organoleptik warna panelis lebih menyukai F2 dibandingkan F1 dan F3 karena pada F2 komposisi temulawak lebih besar dari komposisi temulawak pada F1 dan F3, hal ini menyebabkan warna minuman serbuk 'Terai' F2 lebih pekat (kuning) dibanding F1 dan F3.

b. Daya Terima Organoleptik Mutu Tekstur Minuman Serbuk 'Terai'

Hasil penelitian minuman serbuk 'Terai' menunjukkan bahwa nilai rata-rata responden tertinggi atau yang paling disukai pada mutu tekstur adalah F1 dengan nilai 3,3. Hasil analisis statistik antara F1, F2 dan F3 menunjukkan bahwa nilai signifikansi $p>0,05$ yaitu $p=0,288$, artinya bahwa tidak ada perbedaan yang nyata antara tekstur F1, F2, dan F3. Hal ini dikarenakan pada penelitian minuman serbuk 'Terai' dilakukan penambahan air dengan komposisi yang sama yaitu $150 \mathrm{ml}$ air hangat pada setiap formula saat penyeduhan minuman, jadi tidak mempengaruhi kekentalan pada minuman serbuk 'Terai' yang disajikan. Hal ini sejalan dengan penelitian (Moehady, 2015) dan (Arisanti \& Mutsyahidan, 2017) dimana pada penelitian yang telah dilakukan mutu tekstur tidak dinilai secara signifikan karena menggunakan penambahan air yang sama antar formulasi.

c. Daya Terima Organoleptik Mutu Aroma Minuman Serbuk 'Terai'

Hasil penelitian minuman serbuk 'Terai' menunjukkan bahwa nilai rata-rata responden tertinggi atau yang paling disukai pada mutu aroma adalah yaitu F3 dengan nilai 3,27, hasil ini tidak berbanding jauh pada F1 (3) dan F2 (2,97). Analisis statistik pengaruh F1, F2 dan F3 menunjukkan bahwa tidak ada pengaruh antara daya terima minuman serbuk 'Terai' mutu organoleptik aroma $(\mathrm{p}=0,273)$. Hasil penelitian ini menjelaskan bahwa tidak ada perbedaan yang signifikan aroma antara F1, F2, dan F3. 
Penelitian (Widiastuti, Anggi, dkk, 2018) menunjukkan bahwa semakin banyak penggunaan serai maka semakin tinggi rasa suka terhadap suatu olahan, karena serai memiliki kandungan geraniol yang beraroma wangi dan khas. Namun pada penelitian ini karena serai diolah dalam bentuk serbuk, jadi aroma minuman serbuk serai tidak setajam aroma olahan yang langsung menggunakan serai dalam bentuk batang ataupun sarinya, sehingga saat uji mutu aroma dilakukan sulit membedakan aroma antar formula.

\section{d. Daya Terima Organoleptik Mutu Rasa Minuman Serbuk 'Terai'}

Hasil penelitian minuman serbuk 'Terai' menunjukkan bahwa nilai rata-rata responden tertinggi atau yang paling disukai adalah F2 dengan nilai 3,6. Analisis statistik pengaruh F1, F2 dan F3 menunjukkan bahwa nilai signifikansi $p=0,004$, yang artinya bahwa ada perbedaan yang nyara antara rasa F1, F2, dan F3. Hal ini dikarenakan pada penelitian minuman serbuk 'Terai' dilakukan perbandingan yang berbeda antara serbuk temulawak dan serbuk serai pada F1, F2, dan F3 yang dapat mempengaruhi rasa dari setiap formula. Penelitian (Widiastuti, Anggi, dkk, 2018) menunjukkan bahwa hasil uji organoleptik minuman berbahan dasar serai dari mutu rasa yang paling disukai adalah dengan deskripsi sedikit manis.

Pada penelitian ini didapatkan F2 yang paling disukai dengan komposisi serbuk serai paling sedikit, dimana serbuk temulawak dengan komposisi $6 \mathrm{~g}$ dan serbuk serai dengan komposisi 1,5 g menghasilkan kombinasi rasa yang pas yaitu sedikit pahit yang berasal dari rasa khas temulawak dan rasa manis yang pas dari gula yang terkandung dalam masing-masing serbuk temulawak dan serbuk serai.

e. Uji Karakteristik Kadar Air Minuman Serbuk 'Terai'

Berdasarkan pemeriksaan uji karakteristik kadar air yang dilakukan pada minuman serbuk 'Terai' didapatkan hasil kadar air adalah 7,22\%, dimana jika dibandingkan dengan syarat mutu kadar air minuman serbuk menurut SNI yaitu maksimal 3.0\%, hasil kadar air minuman serbuk 'Terai masih dibawah syarat mutu kadar air menurut SNI.

Pada penelitian ini temulawak dan serai merupakan bahan utama dalam pembuatan minuman serbuk 'Terai', dimana perbandingan kombinasi antara temulawak dan serai akan mempengaruhi kadar air minuman serbuk 'Terai'. Temulawak segar 
mengandung air sekitar 75\% dan serai segar mengandung air sekitar 14\%. Pada penelitian (Rakhmad, 2017) menyebutkan bahwa kadar air pada minuman serbuk tergantung pada suhu pengeringan saat pengolahan, dimana semakin tinggi suhu pengeringan maka kadar air dari minuman serbuk juga akan semakin rendah. Adapun beberapa faktor yang mempengaruhi pengeringan produk pangan diantaranya adalah suhu pengeringan yang digunakan, lama pengeringan (waktu), metode pengeringan dan sifat dan bentuk bahan.

Berdasarkan faktor yang dapat mempengaruhi pengeringan produk pangan maka juga berkaitan dengan tingginya kadar air pada minuman serbuk 'Terai'. Dilihat dari segi metode yang digunakan pada pengolahan minuman serbuk 'Terai' masih menggunakan metode manual, yaitu pemasakan dilakukan secara langsung di wajan diatas api sedang, kemudian dilihat dari segi waktu pengeringan, pada penelitian ini waktu pemasakan berlangsung selama kurang lebih 90 menit, jika waktu pemasakan ditambah menjadi lebih lama, maka akan membuat serbuk menjadi gosong dan terasa pahit, hal ini dapat disebabkan karena pada pembuatan minuman serbuk 'Terai' menggunakan gula sebagai bahan metode kritalisasi. Kadar air pada temulawak dan serai segar juga berpengaruh pada kadar air minuman serbuk 'Terai', dimana pada pada penelitian ini formula yang paling disukai adalah formula yang lebih banyak mengandung temulawak dengan kadar air bahan segar 75\%, maka hal ini juga mempengaruhi kadar air pada minuman serbuk 'Terai'.

Pada penelitian (Alfonsius., Sinung, P., Ekawati, 2015) menghasilkan minuman serbuk dengan kadar air 3,08\% - 3,58\% dari proses pengeringan menggunakan oven bersuhu $80^{\circ} \mathrm{C}$ selama 12 jam dengan variasi penambahan maltodekstrin. Kemudian pada penelitian (Ariska \& Utomo, 2020) menghasilkan minuman serbuk dengan kadar air terbaik 5,795\% dari proses pengeringan meggunakan oven dengan suhu $70^{\circ} \mathrm{C}$ selama 7 - 8 jam. Kemudian pada penelitian (Cahyono et all, 2011) menghasilkan minuman serbuk temulawak dengan kadar air $4,06^{\circ} \mathrm{C}-7,76^{\circ} \mathrm{C}$ dengan pengeringan menggunakan oven pada suhu $60^{\circ} \mathrm{C}$ dan pengeringan menggunakan lampu dengan daya sebesar 30 watt dengan suhu $30^{\circ} \mathrm{C}$ dan variasi lama pengeringan 1 hari, 3 hari, dan 5 hari. 


\section{f. Uji Karakteristik Kadar Abu Minuman Serbuk 'Terai'}

Berdasarkan pemeriksaan uji karakteristik kadar abu yang dilakukan pada minuman serbuk 'Terai' didapatkan hasil kadar abu adalah 2,11\%, dimana jika dibandingkan dengan syarat mutu kadar abu minuman serbuk menurut SNI yaitu maksimal 1,5\%, hasil kadar abu minuman serbuk 'Terai masih dibawah syarat mutu kadar abu menurut SNI.

Pada penelitian (Arisanti \& Mutsyahidan, 2017) menyebutkan bahwa abu merupakan residu organik dari pembakaran bahan - bahan organik, biasanya komponen tersebut terdiri dari kalium, kalsium, natrium, besi, mangan dan magnesium. Karena minuman serbuk 'Terai' dengan formulasi yang paling disukai memiliki kandungan air yang tinggi, maka kandungan air yang tinggi tersebut akan menyebabkan kandungan mineral juga tinggi, sehingga berpengaruh pada kadar abu minuman serbuk 'Terai'. Hal ini sesuai dengan penelitian (Alfonsius., Sinung, P., Ekawati, 2015) menghasilkan minuman serbuk dengan kadar air 3,08\% - 3,58\% dan dengan kadar abu $0,19 \%-0,3 \%$.

\section{SIMPULAN DAN SARAN}

Berdasarkan penelitian yang telah dilakukan pada minuman serbuk 'Terai, maka dapat disimpulkan bahwa dari minuman serbuk 'Terai' yang paling disukai adalah perlakuan F2 dengan komposisi serbuk temulawak $6 \mathrm{~g}$ dan serbuk serai 1,5 g dan mengandung kadar air 7,22\% serta kadar abu 2,11\%.

Sarannya adalah melakukan pengembangan terkait minuman serbuk dengan variable yang berbeda. 


\section{DAFTAR RUJUKAN}

Alfonsius., Sinung, P., Ekawati, P. (2015). Kualitas Minuman Serbuk Instan Kayu Secang (Caesalpinia sappan L.) dengan Variasi Maltodekstrin. Jurnal Universitas Atma Jaya, 30(1), 3 .

Anariawati. (2009). Studi Eksperimen Pembuatan Serbuk Instan Kayu Secang (Caesalpinia Sappan) dengan Menggunakan Jumlah Gula yang Berbeda Sebagai Minuman Berkhasiat.

Arisanti, D., \& Mutsyahidan, A. M. A. (2017). Karakterisitik Sifat Fisikokimia Teh Herbal "Sekam" (Serai Kombinasi Kayu Manis) Sebagai Minuman Fungsional. JTech, 6(2), 62-66. Retrieved from https://doi.org/10.30869/jtech.v6i2.199

Ariska, S. B., \& Utomo, D. (2020). Kualitas minuman serbuk instan sereh (Cymbopogon citratus) dengan metode foam mat drying. Teknologi Pangan: Media Informasi Dan Komunikasi Ilmiah Teknologi Pertanian, 11(1), 42-51. https://doi.org/10.35891/tp.v11i1.1903

Balitro. (2011). Standar Operasional Prosedur (SOP) Budidaya Temulawak (Curcuma xanthorrhiza Roxb). 1-16.

Br. Sembiring, B., Ma'mun, \& Ginting, E. I. (2015). Pengaruh Kehalusan Bahan dan Lama Ekstraksi Terhadap Mutu Eekstrak Temulawak (Curcuma Xanthorriza Roxb). Buletin Penelitian Tanaman Rempah Dan Obat, 17(2), 53-58. https://doi.org/10.21082/bullittro.v17n2.2006.

Budiasih, K. S. (2011). Pemanfaatan Beberapa Tanaman yang Berpotensi Sebagai Bahan Anti Nyamuk. 1-8.

Cahyani, D. I., \& Rustanti, N. (2015). Pengaruh Penambahan Teh Hijau Terhadap Aktivitas Antioksidan Dan Kadar Protein Minuman Fungsional Susu Kedelai Dan Madu. Journal of Nutrition College, 4(4), 394-399. https://doi.org/10.14710/jnc.v4i4.10116

Cahyono, B., Huda, M. D. K., \& Limantara, L. (2011). Pengaruh Proses Pengeringan Rimpang Temulawak (Curcuma Xanthorriza Roxb) Terhadap Kandungan dan $\begin{array}{llll}\text { Komposisi Kurkuminoid. } & \text { Reaktor, } & \text { 13(3), }\end{array}$ https://doi.org/10.14710/reaktor.13.3.165-171

Ewansiha, Garba, Mawak, \& Oyewole. (2012). Antimicrobial Activity of Cymhopogon Citratus (Lemon Grass) and It's Phytochemical Properties. Frontiers in Science, 2(6), 214-220. Retrieved from http://irepos.unijos.edu.ng/jspui/bitstream/123456789/439/1/Antimicrobial Activity Of Cymbopogon Citratus Lemon Grass And Its Phytochemical Properties.pdf

Fitriyoni Ayustaningwarno. (2014). Teknologi Pangan. Teori Praktis Dan Aplikasi. Haryanto, B. (2017). Pengaruh Penambahan Gula Terhadap Karakteristik Bubuk Instan 
Daun Sirsak (Annona Muricata L.) Dengan Metode Kristalisasi. Jurnal Penelitian Pascapanen Pertanian, 14(3), 163. https://doi.org/10.21082/jpasca.v14n3.2017.163-170 Jambi, D. R. (2018). Kompilasi Pemikiran Dewan Riset Daerah Provinsi Jambi. In Repository.Unja.Ac.Id. Retrieved from https://repository.unja.ac.id/7178/4/Buku kompilasi_DRD.pdf\#page $=27$

Kristiani, B. R. (2013). Kualitas Minuman Serbuk Effervescent Serai (Cymbopogon nardus L. Rendle) Dengan Variasi Konsentrasi Asam Sitrat dan Na-bikarbonat. Moehady, B. I. (2015). Serbuk Temulawak Sebagai Bahan Baku Minuman. 55-60.

Monicca, A. G. (2018). Pengaruh Variasi Kondisi pH dan Perbandingan Sari Temulawak Dengan Sukrosa Terhadap Karakteristik Minuman Serbuk Temulawak (Curcuma Xanthorriza Roxb.) Dengan Metode Ko-Kristalisasi. E-Conversion Proposal for a Cluster of Excellence.

Prodi Tekpang UMS. (2013). Pengujian Organoleptik. Universitas Muhammadiyah Semarang, 6-32.

Rahardjo, M. (2015). Penerapan SOP Budidaya Untuk Mendukung Temulawak Sebagai Bahan Baku Obat Potensial. Perspektif, 9(2), 78-93. https://doi.org/10.21082/p.v9n2.2010.\%p

Rakhmad, W. (2017). Studi Pembuatan Serbuk Effervescent Temulawak (Curcuma Xanthorrhiza Roxb) Kajian Suhu Pengering, Konsentrasi Dekstrin, dan Na-Bikarbonat. Jurnal Teknologi Pangan, 1(1), 1-31. Retrieved from http://jurnal.yudharta.ac.id/v2/index.php/Teknologi-Pangan/article/view/477

Saparingga. (2012). Aktivitas Antioksidan Dan Kualitas Es Krim Tradisional Labu Kuning (Cucurbita Muschata) Dengan Penambahan Ekstrak Kulit Buah Naga Merah Sebagai Pewarna Alami. Naskah Publikasi.

SNI. (1996). Serbuk Minuman Tradisional.

Syamsudin, R. aldizal mahendra riziko, Perdana, F., Mutiaz, firly suci, Galuh, V., Rina, apriliani putry ayu, Cahyani, novia dwi, ... Khendri, F. (2019). Review: Tanaman Temulawak (Curcuma xanthorrhiza Roxb) sebagai Obat Tradisional. Jurnal Ilmiah Farmako Bahari, 10(1), 51-65. Retrieved from https://journal.uniga.ac.id/index.php/JFB

Widiastuti, A., Anindya, R. N., \& Harismah, K. (2018). Minuman Fungsional dari Serai (Cymbopogon Citratus) dan Pemanis Stevia. 628-632.

Widyantari. (2020). Formulasi Minuman Fungsional Terhadap Aktivitas Antioksidan. E-Journal Widya Kesehatan, 2, 22-29. 
Winda, R. N. T., \& Tri, D. W. (2014). Jurnal Review : Potensi Cincau Hitam (Mesona Palustris BI.), Daun Pandan (Pandanus Amaryllifolius) dan Kayu Maanis (Cinnamomum Burmannii) Sebagai Bahan Baku Minuman Herbal Fungsional. 19(4), 320-326. 